OPEN ACCESS

Edited by:

Thomas Bartholomäus Brück

Technical University of

Munich, Germany

Reviewed by:

Amir Feizi,

Chalmers University of

Technology, Sweden

Daniela Monti,

Italian National Research Councl

(CNR), Italy

*Correspondence:

Fuping Lu

Ifp@tust.edu.cn

Specialty section:

This article was submitted to

Bioprocess Engineering,

a section of the journal

Frontiers in Bioengineering and

Biotechnology

Received: 21 February 2019

Accepted: 23 May 2019

Published: 11 June 2019

Citation:

Peng C, Shi C, Cao X, Li Y, LiU F and Lu F (2019) Factors Influencing Recombinant Protein Secretion Efficiency in Gram-Positive Bacteria:

Signal Peptide and Beyond

Front. Bioeng. Biotechnol. 7:139.

doi: 10.3389/fbioe.2019.00139

\section{Factors Influencing Recombinant Protein Secretion Efficiency in Gram-Positive Bacteria: Signal Peptide and Beyond}

\author{
Chong Peng ${ }^{1,2,3,4}$, Chaoshuo Shi ${ }^{4}$, Xue Cao ${ }^{4}, \mathrm{Yu} \mathrm{Li}^{1,2,3,4}$, Fufeng Liu ${ }^{1,2,3,4}$ and Fuping $\mathrm{Lu}^{1,2,3,4 *}$ \\ ${ }^{1}$ Key Laboratory of Industrial Fermentation Microbiology, Education Ministry of China, Tianjin, China, ${ }^{2}$ National Engineering \\ Laboratory for Industrial Enzymes, Tianjin, China, ${ }^{3}$ Tianjin Engineering Research Center of Microbial Metabolism and \\ Fermentation Process Control, Tianjin, China, ${ }^{4}$ College of Biotechnology, Tianjin University of Science and Technology, \\ Tianjin, China
}

Signal peptides are short peptides directing newly synthesized proteins toward the secretory pathway. These $\mathrm{N}$-terminal signal sequences are ubiquitous to all prokaryotes and eukaryotes. Signal peptides play a significant role in recombinant protein production. Previous studies have demonstrated that the secretion amount of a given target protein varies significantly depending on the signal peptide that is fused to the protein. Signal peptide selection and signal peptide modification are the two main methods for the optimization of a recombinant protein secretion. However, the highly efficient signal peptide for a target protein with a specific bacterial expression host is not predictable so far. In this article, we collect several signal peptides that have previously performed well for recombinant protein secretion in gram-positive bacteria. We also discuss several factors influencing recombinant protein secretion efficiency in gram-positive bacteria. Signal peptides with a higher charge/length ratio in n-region, more consensus residues at the-3 and-1 positions in c-region and a much higher proportion of coils are more likely to perform well in the secretion of recombinant proteins. These summaries can be utilized to the selection and directed modification of signal peptides for a given recombinant protein.

Keywords: signal peptide, recombinant protein, secretory pathway, gram-positive bacteria, secretion efficiency

\section{INTRODUCTION}

In both eukaryotic and prokaryotic cells, all proteins are synthesized in cytoplasm. Proteins that are destined to enter into the secretory pathway are usually endowed with an N-terminal signal sequence: the signal peptide (SP). SPs are short peptides and usually have a length of 16-30 amino acids. After directing proteins to their specific locations, SPs are removed by signal peptidases (Blobel and Dobberstein, 1975; von Heijne, 1990, 1998; Molhoj and Dal Degan, 2004). Research on SPs is quite appealing in the field of protein secretion mechanism. Additionally, research about SPs is valuable in medical research such as disease diagnosis and treatment. For example, mutation in the preproinsulin signal peptide is associated with the onset of diabetes (Bonfanti et al., 2009). A new identified variant in SP of the human luteinizing hormone receptor (LHCGR) affects receptor 
biogenesis and would cause Leydig cell hypoplasia (Vezzoli et al., 2015). Jarjanazi et al. (2008) carried out a comprehensive literature survey and retrieved 26 disease associated mutations in the signal peptide domains of 21 human proteins (Jarjanazi et al., 2008).

Signal peptides also play a decisive role in the industrial production of recombinant proteins. There is a tremendously strong market demand for recombinant proteins such as industrial enzymes and biopharmaceutical proteins (Walsh, 2018). Different prokaryotic and eukaryotic expression systems have been developed to produce recombinant proteins. Among them, bacterial systems are most attractive because they are simple to manipulate and cost-effective (Terpe, 2006). However, the accumulation of recombinant proteins in the cytoplasm will lead to the formation of inclusion bodies or protein degradation via proteases (Mergulhao et al., 2005; Anne et al., 2016). The recombinant protein folding may also be disturbed by endogenous proteins. If the recombinant protein is secreted out of the cell, the above bottlenecks in the mass production of recombinant proteins can be avoided, and the downstream recovery process of protein production will also be considerably simplified. Thus, developing an efficient secretion system will contribute a lot in the high yield of recombinant proteins (Quax, 1997). It has been shown that using different homologous or heterologous signal peptides can affect the yields of recombinant proteins (Degering et al., 2010; Low et al., 2013; Hemmerich et al., 2016; Kleiner-Grote et al., 2018). Selecting a proper signal peptide to increase the secretion efficiency becomes a common methodology to optimize the production of recombinant protein.

Gram-positive bacteria usually consist of only one cell membrane. The secretion of a target protein in gram-positive bacteria is thought to be more efficient (Freudl, 2013; Anne et al., 2016). Various gram-positive bacteria, especially the generally recognized as safe (GRAS) gram-positive model bacterium Bacillus subtilis (Sewalt et al., 2016), are widely utilized for expression of recombinant proteins in biotechnology (Sone et al., 2015; Anne et al., 2016; Freudl, 2018). Several different protein export systems have been identified in grampositive bacteria to date, including the general secretion (Sec) pathway, the twin-arginine translocation (Tat) pathway and type VII/WXG100 secretion systems. Figures 1A,B are the schematic figures of $\mathrm{Sec}$ and Tat export pathways in grampositive bacteria. Sec-dependent proteins are translocated to the plasma membrane either co- or post-translationally (Figure 1A). In the co-translational export mode, precursor proteins are recognized at the ribosome by the signal recognition particle (SRP) and then targeted to the transmembrane SecYEG channel by SRP and FtsY, the SRP membrane receptor (Elvekrog and Walter, 2015). In the post-translational export mode, the posttranslationally interacting proteins (PIP's), such as the general chaperones GroELS, DnaK-DnaJ-GrpE, trigger factor, the CsaA protein and the soluble form of SecA, keep the fully synthesized precursor proteins in an unfolded secretion-competent state (Wu et al., 1998; Herbort et al., 1999). Then the motor protein SecA translocates the preproteins through SecYEG using metabolic energy from ATP hydrolysis (Schiebel et al., 1991). In addition, SecDF enhances the release of preproteins (Tsukazaki et al., 2011). Tat-dependent proteins are transported across lipid bilayers in a folded state (Figure 1B). The energy for translocation comes from the proton motive force (PMF). In gram-positive bacteria with high GC-content genomes, the Tat translocase consists of TatA, TatB, and TatC. In low-GC grampositive bacteria, the Tat system is composed of TatC and a bifunctional TatA protein (Goosens et al., 2014). These two and other different types of secretion machinery have been wellreviewed in several excellent articles (Palmer and Berks, 2012; Freudl, 2013; Goosens et al., 2014; Ates et al., 2016; Green and Mecsas, 2016; Tsirigotaki et al., 2017; Owji et al., 2018). Readers can refer to these reviews for a better understanding of the protein secretory mechanisms in gram-positive bacteria.

Based on the export pathways of the preproteins and the signal peptidase cleavage sites, signal peptides can be classified into several categories, among which Sec-type signal peptides and twin-arginine signal peptides are more abundant and wellstudied (Tjalsma et al., 2000, 2004). Signal peptides from different proteins show a common structure. Generally, a signal peptide is composed of three distinct domains: a positively charged nregion (1-5 residues long), a central, hydrophobic h-region (7-15 residues long), and a c-region (3-7 residues) with the cleavage site of signal peptidase (von Heijne, 1985, 1990). The general structure of signal peptides is shown in Figure 1C. A highly conserved twin-arginine motif (SRRXFLK, where X is often, but not always, a polar amino acid residue) is located at the $n / h$ region boundary of Tat-specific signal peptides (Berks, 1996; Berks et al., 2000). Several bioinformatic tools have been built and maintained by different research groups to predict signal peptides, such as SignalP (Petersen et al., 2011), Phobius (Kaell et al., 2007), PrediSi (Hiller et al., 2004) for Sec-type signal peptides and TatP (Bendtsen et al., 2005), Tatfind Server (Rose et al., 2002), PRED-TAT (Bagos et al., 2010) for twin-arginine signal peptides (Caccia et al., 2013).

This article is a brief review of factors that influence signal peptide secretion efficiency for recombinant protein in grampositive bacteria, especially in B. subtilis. We summarize several experimental achievements in the screening of a proper signal peptide for a given protein. We also discuss the differences between good-performing and bad-performing signal peptides for different recombinant proteins in B. subtilis. Additionally, other factors including the pro-region of recombinant protein and the expression host are also summarized in the last part.

\section{OPTIMIZATION OF RECOMBINATION PROTEIN SECRETION BY SIGNAL PEPTIDE SCREENING}

Generating a signal peptide library has proven to be a practicable approach for the optimal secretion of recombinant proteins in Gram-positive expression hosts. The first effort to systematically search the best-performing signal peptide for heterologous protein secretion was performed a decade ago. In this study, a signal peptide library consisting of 173 predicted Sec-type SPs from B. subtilis strain 168 was 


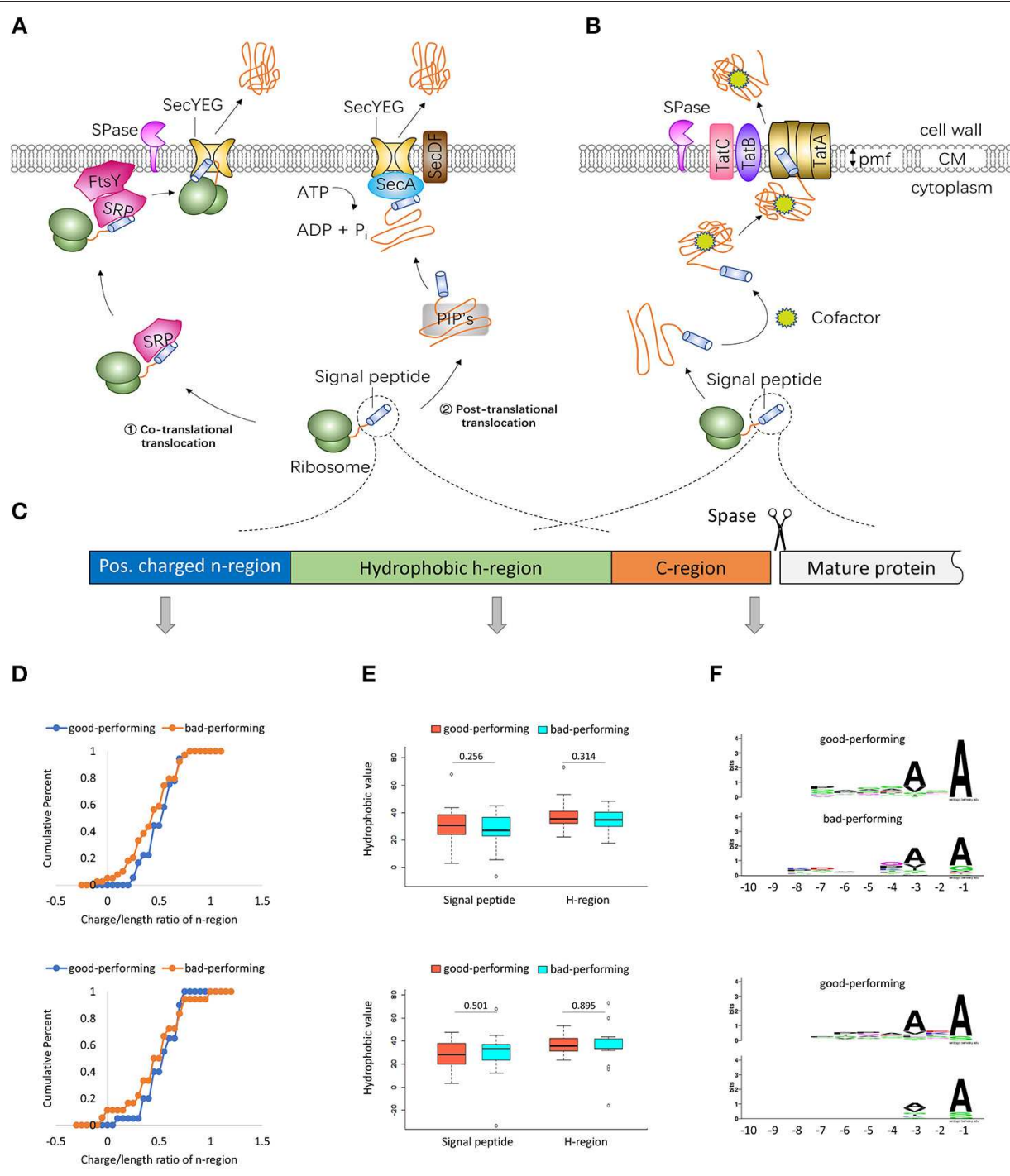

G
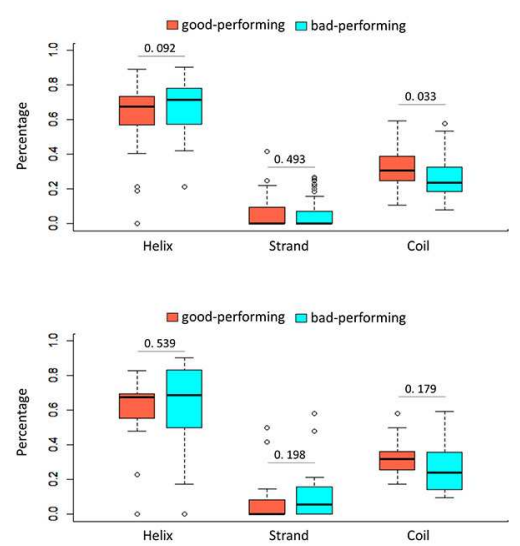

H
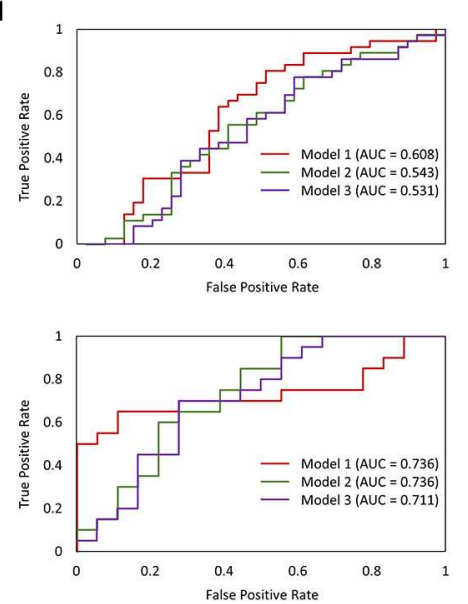

FIGURE 1 | Two major gram-positive bacterial export pathways and signal peptides with different secretion efficiencies. (A) The general secretion (Sec) protein export pathway in gram-positive bacteria. (1). In the co-translational export mode, preproteins are recognized at the ribosome by the signal recognition particle (SRP). Then the SRP membrane receptor FtsY binds to the ribosome-nascent chain (RNC)-SRP complex. SRP and FtsY target the preproteins to the transmembrane

(Continued) 
FIGURE 1 | SecYEG channel. (2). In the post-translational export mode, precursor proteins are fully synthesized and are kept in an unfolded secretion-competent state by the post-translationally interacting proteins (PIP's), such as the general chaperones GroELS/DnaK-DnaJ-GrpE/trigger factor, the CsaA protein and the soluble form of SecA. Then the motor protein SecA translocates the preproteins through SecYEG using metabolic energy from ATP hydrolysis. SecDF enhances the release of preproteins. (B) The twin-arginine translocation (Tat) export pathway in Gram-positive bacteria. After being synthesized, the Tat-dependent pre-protein folds rapidly into its native conformation, sometimes with the help of cofactors. The energy for translocation comes from the proton motive force (PMF). In gram-positive bacteria with high GC-content genomes, the Tat translocase consists of TatA, TatB, and TatC. In low-GC gram-positive bacteria, the Tat system is composed of TatC and a bifunctional TatA protein. (C) The general structure of signal peptides. Adapted by permission from Springer Nature Customer Service Center GmbH: Springer Nature, Nature Biotechnology (Molhoj and Dal Degan, 2004), copyright 2004. (D) Cumulative distributions of the charge/length ratio of $n$-region in good-performing and bad-performing signal peptides. (E) Boxplots of the total hydrophobic values of signal peptides and the hydrophobic values in h-regions. (F) Sequence logos of c-region aligned by their cleavage sites in good-performing and bad-performing signal peptides. (G) Boxplots of the proportions of helices, strands, and coils in good-performing and bad-performing signal peptides. (H) ROC curves of models trained with 1 parameter (dark red), 26 parameters (dark green), and 29 parameters (purple). The data used in the upper half of (D-H) are from Brockmeier et al.'s study (2006). Good-performing SPs are the top 36 SPs showing high cutinase activity (top $25 \%$ of all SPs). Bad-performing SPs are the 39 SPs showing no cutinase activity (the lower $27 \%$ of all SPs). The data used in the bottom half of (D-H) are from Zhang et al.'s study (2016). For the 114 Sec-type signal peptides with promoter P43, the top 20 SPs with Xylanase activity > 100 units/ml are selected as good-performing signal peptides. The last 18 SPs with Xylanase activity $<1$ units/ml are selected as bad-performing signal peptides.

constructed (Brockmeier et al., 2006). The functionality of each SP was studied using cutinase from Fusarium solani pisi as the reporter protein. B. subtilis TEB1030 was used to express the SP-cutinase fusions. This study reveals that the enzymatic activities of cutinase vary significantly when different SPs were fused to the protein. A similar conclusion was also obtained in the comprehensive analysis of signal peptide functionality from Lactobacillus plantarum. Mathiesen et al. (2009) constructed a library of 76 Sec-type signal peptides from L. plantarum WCFS1. Staphylococcal nuclease (NucA) was used as the reporter protein. This screening showed considerable variation in the levels of secreted NucA (Mathiesen et al., 2009). In another experiment, 405 candidate signal peptides were predicted in the completely sequenced genome of Corynebacterium glutamicum R. Then each of the SPs was fused to a heterologous $\alpha$-amylase (AmyE) from Geobacillus stearothermophilus. A total of 108 SPs were shown to mediate detectable secretion of AmyE from the expression host $C$. glutamicum R. Eleven of these samples exhibited 50- to 150fold higher secretion level than that of the signal peptide derived from the well-known corynebacterial secretory protein PS2 (Watanabe et al., 2009).

A promoter is defined as the region of DNA sequence that initiates the gene transcription (Wrighton, 2018). Promoters are often used together with signal peptides as regulatory elements for the expression and production of recombinant proteins (Guan et al., 2016; Gu et al., 2017; Maffei et al., 2017; Cui et al., 2018). Zhang et al. (2016) performed an experimental screen of 138 signal peptides from $B$. subtilis for the production of an alkali-tolerant xylanase (XynBYG) from Bacillus pumilus BYG. They used B. subtilis WB700 as the expression host. Two promoters (Pglvm and the constitutive promoter P43) were separately used in the expression of the protein. The yields of XynBYG using Pglvm promoter were higher than using the $\mathrm{P} 43$ promoter, which indicated that Pglvm promoter is more efficient than the $\mathrm{P} 43$ promoter for XynBYG expression. In further analysis, an obvious correlation with a Pearson correlation coefficient of 0.97 was observed between the yields of XynBYG driven by the two promoters. In other words, good-performing SPs would have higher secretion efficiency than bad-performing SPs no matter which promoter is used in the expression of the protein, and vice versa. This work indicates that promoters do not affect the secretion performance of signal peptides. If a signal peptide performs well when using promoter $\mathrm{A}$ in the expression of the target protein, it will also perform well when promoter $\mathrm{B}$ is used (Zhang et al., 2016).

Signal peptide library construction followed by high-through screening has also been reported in the secretion of several recombinant proteins (Degering et al., 2010; Tsuji et al., 2015; Cai et al., 2016; Hemmerich et al., 2016). Featured with high efficiency and high coverage of SPs, this method has screened many goodperforming signal peptides for different recombinant proteins. Table 1 shows the signal peptides that have previously performed well in gram-positive bacteria. Apart from the signal peptide library-based method, there are also plenty of researches, too numerous to be entirely listed, in which a few signal peptides are involved (Freudl, 2018; Kalbarczyk et al., 2018; Owji et al., 2018). If the secretion efficiencies of these SP-protein combinations are gathered up in specific database, they will be of great value for signal peptide selection and further data analysis.

\section{PRIMARY AND SECONDARY STRUCTURE OF SIGNAL PEPTIDES WITH DIFFERENT SECRETION EFFICIENCIES}

All researches mentioned in the previous section come to the unanimous conclusion that the secretion levels of recombinant protein differ significantly when different SPs are fused to the protein. In other words, the physicochemical properties of SPs may affect the secretion levels of recombinant proteins. To further explore the factors that determine the secretion efficiency of SPs, biologists would also perform some statistical analysis between the yields of target proteins and signal peptide characters such as lengths, charges, $\mathrm{pI}$ values, D-scores from SignalP and so on (Zhang et al., 2016; Fu et al., 2018). In this section, we will try to investigate the differences between good-performing and bad-performing signal peptides by in silico analysis of SPs.

The in silico analysis are performed with 143 Sec-type signal peptides in Brockmeier et al.'s (2006) study and 114 Sec-type signal peptides in Zhang et al.'s (2016) study. For Brockmeier et al.'s data, the top 36 SPs (25\% of all SPs) showing high cutinase activity are selected as good-performing signal peptides. The 39 
TABLE 1 | Examples of several signal peptides that perform well in gram-positive bacteria.

\begin{tabular}{|c|c|c|c|c|c|c|c|}
\hline \multicolumn{2}{|l|}{ Signal peptide } & \multicolumn{2}{|c|}{ Recombinant protein } & \multirow[t]{2}{*}{ Host } & \multirow[t]{2}{*}{ Yield } & \multirow[t]{2}{*}{ Ranking } & \multirow[t]{2}{*}{ Reference } \\
\hline Signal sequence & Origin & Protein & Origin & & & & \\
\hline $\begin{array}{l}\text { MKNMSCKLVVST } \\
\text { LFFSFLTIGPLAHA }\end{array}$ & $\begin{array}{l}\text { B. subtilis, } \\
\text { Epr }\end{array}$ & Cutinase & F. solani pisi & $\begin{array}{l}\text { B. subtilis } \\
\text { TEB1030 }\end{array}$ & $4.67[\mathrm{U} / \mathrm{mL}]$ & $1 / 173$ & $\begin{array}{l}\text { Brockmeier } \\
\text { et al., } 2006\end{array}$ \\
\hline $\begin{array}{l}\text { MAKPLSKGGILVKKVLIAGA } \\
\text { VGTAVLFGTLSSGIPGLPAADAQVAKA }\end{array}$ & $\begin{array}{l}\text { B. subtilis, } \\
\text { YncM }\end{array}$ & Aminopeptidase & $\begin{array}{l}\text { B. subtilis } \\
\text { Zj016 }\end{array}$ & B. subtilis WB600 & $\begin{array}{l}88.59 \\
{[U / m L]}\end{array}$ & $1 / 20$ & $\begin{array}{l}\text { Guan et al., } \\
2016\end{array}$ \\
\hline $\begin{array}{l}\text { MKKFNFKTMLLLVLASCVFGW } \\
\text { VNVITSLGPQTAITAQA }\end{array}$ & $\begin{array}{l}\text { L. } \\
\text { plantarumWCFS1 }\end{array}$ & $\begin{array}{l}\text { NucA } \\
\text { (nuclease) }\end{array}$ & S. aureus & $\begin{array}{l}\text { L. plantarum } \\
\text { WCFS1 }\end{array}$ & $\begin{array}{l}35.84 \\
{[U / m L]}\end{array}$ & $1 / 78$ & $\begin{array}{l}\text { Mathiesen } \\
\text { et al., } 2009\end{array}$ \\
\hline $\begin{array}{l}\text { MKEVRFWGLLLGL } \\
\text { FVCLGAVIPLVSKA }\end{array}$ & $\begin{array}{l}\text { L. } \\
\text { plantarumWCFS1 }\end{array}$ & $\begin{array}{l}\text { AmyA } \\
\text { (amylase) }\end{array}$ & $\begin{array}{l}\text { L. } \\
\text { amylovorus } \\
\text { NRRL } \\
\text { B-4549 }\end{array}$ & $\begin{array}{l}\text { L. plantarum } \\
\text { WCFS1 }\end{array}$ & $\begin{array}{l}3.4 \\
{\left[10^{2} \mathrm{mU} / \mathrm{mL}\right]}\end{array}$ & $1 / 18$ & $\begin{array}{l}\text { Mathiesen } \\
\text { et al., } 2009\end{array}$ \\
\hline $\begin{array}{l}\text { MQINRRGFLKA } \\
\text { TAGLATIGAASMFMPKANA }\end{array}$ & $\begin{array}{l}\text { C. } \\
\text { glutamicum R }\end{array}$ & $\begin{array}{l}\text { AmyE } \\
\text { ( } \alpha \text {-amylase) }\end{array}$ & $\begin{array}{l}\text { G. } \\
\text { stearothermophilu: }\end{array}$ & $\begin{array}{l}\text { C. glutamicum } \\
\text { us }\end{array}$ & $\begin{array}{l}288.3 \\
{[\mathrm{U} / \mathrm{mL}]}\end{array}$ & $1 / 31$ & $\begin{array}{l}\text { Watanabe } \\
\text { et al., } 2009\end{array}$ \\
\hline $\begin{array}{l}\text { MRSKKLWISLLF } \\
\text { ALTLIFTMAFSNMSA }\end{array}$ & $\begin{array}{l}\text { B. } \\
\text { licheniformis } \\
\text { WX-02, AprE }\end{array}$ & Nattokinase & $\begin{array}{l}\text { B. subtilis } \\
\text { natto }\end{array}$ & $\begin{array}{l}\text { B. licheniformis } \\
\Delta \mathrm{OF}-3\end{array}$ & $\begin{array}{l}31.99 \\
{[F U / m L]}\end{array}$ & $1 / 81$ & $\begin{array}{l}\text { Cai et al., } \\
2016\end{array}$ \\
\hline $\begin{array}{l}\text { MKNMSCKLWSVTL } \\
\text { FFSFLTIGPLAHA }\end{array}$ & $\begin{array}{l}\text { B. subtilis, } \\
\text { Epr }\end{array}$ & Cutinase & F. solani pisi & C. glutamicum & $13.1[\mathrm{U} / \mathrm{mL}]$ & $1 / 64$ & $\begin{array}{l}\text { Hemmerich } \\
\text { et al., } 2016\end{array}$ \\
\hline $\begin{array}{l}\text { MKKFPKKLLPIAVL } \\
\text { SSIAFSSLASGSVPEASA }\end{array}$ & $\begin{array}{l}\text { B. subtilis, } \\
\text { PhoB }\end{array}$ & $\begin{array}{l}\text { XynBYG } \\
\text { (alkaline } \\
\text { active } \\
\text { xylanase) }\end{array}$ & $\begin{array}{l}\text { B. pumilus } \\
\text { BYG }\end{array}$ & B. subtilis WB700 & $\begin{array}{l}327.2 \\
{[U / \mathrm{mL}]}\end{array}$ & $1 / 138$ & $\begin{array}{l}\text { Zhang et al., } \\
2016\end{array}$ \\
\hline $\begin{array}{l}\text { MRSKKLWISLLFAL } \\
\text { TLIFTMAFSNMSVQA }\end{array}$ & $\begin{array}{l}\text { B. subtilis 168, } \\
\text { AprE }\end{array}$ & $\begin{array}{l}\text { Alkaline } \\
\text { protease }\end{array}$ & $\begin{array}{l}\text { B. } \\
\text { alcalophilus } \\
\text { TCCC11004 }\end{array}$ & B. subtilis WB600 & $\begin{array}{l}7574.08 \\
{[\mathrm{U} / \mathrm{mL}]}\end{array}$ & $1 / 35$ & Our lab \\
\hline $\begin{array}{l}\text { MRIFKKAVFVIMI } \\
\text { SFLIATVNVNTAHA }\end{array}$ & $\begin{array}{l}\text { B. subtilis } \\
\text { 168, DacB }\end{array}$ & $\begin{array}{l}\text { Alkaline } \\
\text { protease }\end{array}$ & $\begin{array}{l}\text { B. } \\
\text { alcalophilus } \\
\text { TCCC11004 }\end{array}$ & $\begin{array}{l}\text { B. } \\
\text { amyloliquefaciens } \\
111018\end{array}$ & $\begin{array}{l}19835.7 \\
{[\mathrm{U} / \mathrm{mL}]}\end{array}$ & $1 / 86$ & Our lab \\
\hline
\end{tabular}

SPs (27\% of all SPs) showing no cutinase activity are selected as bad-performing signal peptides. For the 114 Sec-type signal peptides with promoter $\mathrm{P} 43$ reported by Zhang et al., the top 20 SPs (with Xylanase activity $>100$ units $/ \mathrm{ml}$ ) are selected as good-performing signal peptides. The last 18 SPs (with Xylanase activity $<1$ units $/ \mathrm{ml}$ ) are selected as bad-performing signal peptides. The analysis results are displayed in Figure $\mathbf{1 .}$

Figure 1D shows the cumulative distributions of the charge/length ratio of $\mathrm{n}$-region in good-performing and badperforming signal peptides. The two panels of Figure 1D reveal that the charge/length ratio of n-region in good-performing SPs is higher than that in bad-performing SPs. Previous studies also proved the importance of positively charged residues in the n-region during the initial step of protein secretion across the membrane. Substitution of positively charged residues with uncharged or negatively charged residues would reduce the protein synthesis rate and transport rate (Inouye et al., 1982; Nesmeyanova et al., 1997). Increasing the positive charge of n-region has been demonstrated to improve secretion efficiency in both gram-positive (Takimura et al., 1997; Ng and Sarkar, 2013) and gram-negative bacteria (Ismail et al., 2011). However, it is notable that the increase in the positive charge is not always favorable. The plots in Figure 1D show the prediction power of the charge/length ratio of n-region can be up to 1 , and it might be not helpful when the value is above 1 . Other studies have shown that increasing the positive charge in n-region reduced the protein secretion (Ravn et al., 2003; Jonet et al., 2012; Gao et al., 2016). We suspect that positively charged residues in $\mathrm{h}$-region and c-region of SP and the mature protein may lead to the contradictory results.

Figure 1E shows the boxplots of the total hydrophobic values in signal peptides and the hydrophobic values in h-regions. The Kyte-Doolittle hydrophobic scale is used in the current study (Kyte and Doolittle, 1982). The Wilcoxon Rank Sum Test reveals that hydrophobic values show no statistically significant differences between good-performing and bad-performing signal peptides $(P$-values $>0.05)$. Previous studies showed that interfering in the h-region hydrophobicity has various effects on protein secretion. For example, reducing the hydrophobicity of Staphylococcus aureus SP completely abolished the secretion of mature protein (Mordkovich et al., 2015). Increasing the hregion hydrophobicity promoted the secretion of the heavy chain of monoclonal antibody in Escherichia coli (Zhou et al., 2016). Substitution of Gly with Cys and Leu in the PhoE SP shifted protein secretion from SecB to SRP-dependent pathway (Adams et al., 2002). It is more likely that the order of residues and the secondary structure they formed in h-region regulate the protein secretion efficiency (Zhang et al., 2016; Han et al., 2017).

We also generate the sequence logos of c-region in goodperforming and bad-performing signal peptides with the 
WebLogo service (Crooks et al., 2004) (Figure 1F). The sequence logos are aligned by their cleavage sites. Data from both Brockmeier et al.'s and Zhang et al.' study show that residues at the -3 and-1positions relative to the signal peptidase cleavage site are more consensus in good-performing SPs than in bad-performing SPs. Alanine residues are more likely to appear at positions-3 and-1 in good-performing signal peptides. Early studies have also shown that the presence of Ala residues at positions -3 and -1 resulted in a considerable improvement in recombinant protein secretion (Ravn et al., 2003; Guan et al., 2015).

Figure 1G shows the boxplots of the proportions of helices, strands and coils in good-performing and bad-performing SPs. The secondary structure of signal peptides are predicted by PSIPRED (Buchan et al., 2013). For Brockmeier et al.'s data (2006), the Wilcoxon Rank Sum Test suggests that goodperforming signal peptides have a much higher proportion of coils (the upper half of Figure 1G). However, the $P$ - values in Zhang et al.'s data (2016) are not significant enough (the bottom half of Figure 1G). In a recent study, a native Sec-type signal peptide and its modified counterpart were used to secrete Candida antarctica Lipase B (CALB) in E. coli. The molecular dynamic simulation shows that the native signal peptide contains an alpha-helix structure, whereas the designed one consists only coils and turns. The secondary structure of designed signal peptide creates a more stable interaction with the signal peptidase. Their results showed that the designed signal peptide increased the secretion of CALB (Ghahremanifard et al., 2018).

According to the above analysis, we suspect that the secondary structure is critical to the secretion efficiency of a signal peptide. Coils help to enhance the interaction between signal peptides and signal peptidases. The positive charge of n-region, the hydrophobicity of h-region and the Ala residues at the -3 and-1positions in c-region may exert indirect effects on the secretion efficiency of the signal peptide through their effects on the secondary structure of the signal peptide.

To test if it is possible to predict SPs performance based on the above sequence and structure features, we developed three support vector machine (SVM)-based models for each of the two data sets. The models were implemented with the software toolbox LIBSVM 3.23 (Chang and Lin, 2011). In model 1, only 1 parameter, the charge/length ratio of n-region, was used. In model 2, a total of 26 parameters including the charge/length ratio of n-region, the hydrophobic values in h-region, the length of SP, the length of N/H/C region and the frequencies of 20 amino acids in each SP (20 features) were used. In model 3, the proportions of helices, strands and coils in SP (3 features) together with the 26 feathers in model 2 were used. The ROC curve in 10-fold cross-validation tests for each model is presented in Figure 1H. The AUC scores of the three models are between 0.53 and 0.61 for Brockmeier et al.'s data (2006). For Zhang et al.'s data (2016), the AUC scores are between 0.71 and 0.74 . Given the immaturity of these models, it would deserve a try to predict SP performance with machine learning methods if more features and more accurate algorithms are added to the prediction models.

\section{OTHER FACTORS INFLUENCING PROTEIN SECRETION EFFICIENCY IN ACTION}

The experimental researches of signal peptide screening also show that the secretion efficiency is at least in part dependent on the protein that is secreted. In Brockmeier et al.'s study, a subset of signal peptides in the SPs library was fused to a cytoplasmatic esterase of metagenomic origin. Surprisingly, the best signal peptide for cutinase secretion was inefficient for esterase and vice versa (Brockmeier et al., 2006). Similarly, in Mathiesen et al.'s study, lactobacillal amylase (AmyA) was also used as the reporter protein with a selected set of SPs. No correlation was observed between the signal peptide performance with NucA and with AmyA. The secretion efficiency of a given signal peptide is changeable when it is fused to different proteins (Mathiesen et al., 2009). The $\sim 30$ residues downstream of the signal sequence, termed the "pro-region," has also been shown to be critical for protein secretion (Andersson and von Heijne, 1991; Low et al., 2013; Musik et al., 2019). Our suspicion is that the pro-region influences protein secretion efficiency through its intervention to the interaction between the signal peptide and signal peptidase.

Degering et al. (2010) constructed a signal peptide library consisting of 173 signal peptides from B. subtilis and 220 signal peptides from Bacillus licheniformis to improve the production of subtilisin protease BPN' from Bacillus amyloliquefaciens ATCC 23844. Three different Bacillus expression strains (B. subtilis TEB1030, B. licheniformis DSM13/MW3, and B. licheniformis strain H402) were used as expression hosts. Both homologous and heterologous signal peptides fused to the target protein can direct protease secretion. Strikingly, the majority of SPBPN' fusions showed similar relative levels of protease secretion in all three Bacillus expression strains (Degering et al., 2010). However, in another study, distantly related organisms are used as expression hosts (Hemmerich et al., 2016). In this research, a signal peptide library consisting of about 150 SPs from low-GC firmicutes $B$. subtilis was constructed. Cutinase from F. solani pisi used by Brockmeier et al. (2006) was also selected as the model enzyme. The SP-cutinase fusions were successfully transferred to high-GC actinobacterium C. glutamicum ATCC13032 as alternative secretion host. The protein secretion levels with the same SP in Brockmeier et al.'s (2006) study (B. subtilis as secretion host) and in this study (C. glutamicum as secretion host) were compared. Interestingly, no correlation was observed between the two sets of data. Videlicet, the cutinase secretion levels directed by the same signal peptide differ dramatically with $B$. subtilis and C. glutamicum as secretion hosts. The results of the two studies show that the phylogenetic distance of expression hosts may affect the secretion performance of specific SP-protein combinations (Hemmerich et al., 2016).

\section{CONCLUSION AND PERSPECTIVES}

Secreting recombinant protein out of the cell can improve the yield and simplify the purification process. A highly efficient signal peptide is of great value in the construction of secretory expression system. Signal peptide library construction followed 
by high-through screening has been successfully applied in the selecting of appropriate signal peptides for a target protein. This technology and other genetic engineering tools such as CRISPER can be further implemented on bacterial systems for the goodperforming SPs selection and recombinant proteins production.

In silico analysis of good-performing and bad-performing signal peptides reveals that good-performing signal peptides have a higher charge/length ratio in $\mathrm{n}$-region and more consensus residues (alanine amino acids are preferred) at the -3 and-1positions in c-region. Moreover, goodperforming signal peptides have a much higher proportion of coils. Except for the signal peptide properties itself, the pro-region of the target protein and the expression host may also influence the secretion efficiency. We speculate that the interaction between the signal peptide and signal peptidase is critical to the recombinant protein secretion efficiency. The primary and secondary structure, as mentioned above, would most likely influence the secretion efficiency of the signal peptide through their effects on the interaction between the signal peptide and signal peptidase. We hope more experimental data can be generated and more regularities about secretion efficiencies can be summed up by bioinformatic approaches. The bioinformatic databases and concluded laws will become great contributors to the selection and directed modification of signal peptides for a given recombinant protein.

\section{REFERENCES}

Adams, H., Scotti, P. A., de Cock, H., Luirink, J., and Tommassen, J. (2002). The presence of a helix breaker in the hydrophobic core of signal sequences of secretory proteins prevents recognition by the signalrecognition particle in Escherichia coli. Eur. J. Biochem. 269, 5564-5571. doi: 10.1046/j.1432-1033.2002.03262.x

Andersson, H., and von Heijne, G. (1991). A 30-residue-long "export initiation domain" adjacent to the signal sequence is critical for protein translocation across the inner membrane of Escherichia coli. Proc. Natl. Acad. Sci. U.S.A. 88, 9751-9754. doi: 10.1073/pnas.88.21.9751

Anné, J., Economou, A., and Bernaerts, K. (2016). "Protein Secretion in GramPositive Bacteria: From Multiple Pathways to Biotechnology," in Protein and Sugar Export and Assembly in Gram-Positive Bacteria, eds F. Bagnoli and R. Rappuoli (Cham: Springer), 267-308. doi: 10.1007/82_2016_49

Ates, L. S., Houben, E. N. G., and Bitter, W. (2016). Type VII secretion: a highly versatile secretion system. Microbiol. Spectr. 4. doi: 10.1128/microbiolspec.VMBF-0011-2015

Bagos, P. G., Nikolaou, E. P., Liakopoulos, T. D., and Tsirigos, K. D. (2010). Combined prediction of Tat and Sec signal peptides with hidden Markov models. Bioinformatics 26, 2811-2817. doi: 10.1093/bioinformatics/btq530

Bendtsen, J. D., Nielsen, H., Widdick, D., Palmer, T., and Brunak, S. (2005). Prediction of twin-arginine signal peptides. BMC Bioinform. 6:167. doi: 10.1186/1471-2105-6-167

Berks, B. C. (1996). A common export pathway for proteins binding complex redox cofactors? Mol. Microbiol. 22, 393-404. doi: 10.1046/j.1365-2958.1996.00114.x

Berks, B. C., Sargent, F., and Palmer, T. (2000). The Tat protein export pathway. Mol. Microbiol. 35, 260-274. doi: 10.1046/j.1365-2958.2000.01719.x

Blobel, G., and Dobberstein, B. (1975). Transfer of proteins across membranes. I. Presence of proteolytically processed and unprocessed nascent immunoglobulin light chains on membrane-bound ribosomes of murine myeloma. J. Cell Biol. 67, 835-851. doi: 10.1083/jcb.67.3.835

Bonfanti, R., Colombo, C., Nocerino, V., Massa, O., Lampasona, V., Iafusco, D., et al. (2009). Insulin gene mutations as cause of diabetes in children

\section{DATA AVAILABILITY}

Publicly available datasets were analyzed in this study. This data can be found here: https://www.sciencedirect.com/science/ article/pii/S0022283606009272 and https://link.springer.com/ article/10.1007\%2Fs00253-016-7615-4.

\section{AUTHOR CONTRIBUTIONS}

FpL conceived and designed the study. CP performed the study and drafted the manuscript. CS, XC, and YL took part in the data collection. FfL took part in the data analysis. All the authors edited the manuscript and approved the final manuscript.

\section{FUNDING}

The present work was supported by The National Key Research and Development Program of China (Grant No 2017YFB0308401) and the public service platform project of fine strain selection and fermentation technology for industrial microbe (Grant No. 17PTGCCX00190).

\section{ACKNOWLEDGMENTS}

The authors would like to thank Prof. Feng Gao in Tianjin University for the invaluable assistance and inspiring discussions.

negative for five type 1 diabetes autoantibodies. Diabetes Care 32, 123-125. doi: $10.2337 / \mathrm{dc} 08-0783$

Brockmeier, U., Caspers, M., Freudl, R., Jockwer, A., Noll, T., and Eggert, T. (2006). Systematic screening of all signal peptides from Bacillus subtilis: a powerful strategy in optimizing heterologous protein secretion in gram-positive bacteria. J. Mol. Biol. 362, 393-402. doi: 10.1016/j.jmb.2006.07.034

Buchan, D. W. A., Minneci, F., Nugent, T. C. O., Bryson, K., and Jones, D. T. (2013). Scalable web services for the PSIPRED protein analysis workbench. Nucleic Acids Res. 41, W349-W357. doi: 10.1093/nar/gkt381

Caccia, D., Dugo, M., Callari, M., and Bongarzone, I. (2013). Bioinformatics tools for secretome analysis. Biochim. Et Biophys. Acta Proteins Proteom. 1834, 2442-2453. doi: 10.1016/j.bbapap.2013.01.039

Cai, D., Wei, X., Qiu, Y., Chen, Y., Chen, J., Wen, Z., et al. (2016). Highlevel expression of nattokinase in Bacillus licheniformis by manipulating signal peptide and signal peptidase. J. Appl. Microbiol. 121, 704-712. doi: $10.1111 /$ jam. 13175

Chang, C.-C., and Lin, C.-J. (2011). LIBSVM: a library for support vector machines. ACM Transac. Intell. Syst. Technol. 2:27. doi: 10.1145/1961189.1961199

Crooks, G. E., Hon, G., Chandonia, J. M., and Brenner, S. E. (2004). WebLogo: a sequence logo generator. Genome Res. 14, 1188-1190. doi: 10.1101/gr.849004

Cui, W. J., Han, L. C., Suo, F. Y., Liu, Z. M., Zhou, L., and Zhou, Z. M. (2018). Exploitation of Bacillus subtilis as a robust workhorse for production of heterologous proteins and beyond. World J. Microbiol. Biotechnol. 34:145. doi: 10.1007/s11274-018-2531-7

Degering, C., Eggert, T., Puls, M., Bongaerts, J., Evers, S., Maurer, K.-H., et al. (2010). Optimization of protease secretion in Bacillus subtilis and Bacillus licheniformis by screening of homologous and heterologous signal peptides. Appl. Environ. Microbiol. 76, 6370-6376. doi: 10.1128/AEM.01 146-10

Elvekrog, M. M., and Walter, P. (2015). Dynamics of co-translational protein targeting. Curr. Opin. Chem. Biol. 29, 79-86. doi: 10.1016/j.cbpa.2015.09.016

Freudl, R. (2013). Leaving home ain't easy: protein export systems in Gram-positive bacteria. Res. Microbiol. 164, 664-674. doi: 10.1016/j.resmic.2013.03.014 
Freudl, R. (2018). Signal peptides for recombinant protein secretion in bacterial expression systems. Microb. Cell Fact. 17:52. doi: 10.1186/s12934-018-0901-3

Fu, G., Liu, J. L., Li, J. S., Zhu, B. W., and Zhang, D. W. (2018). Systematic screening of optimal signal peptides for secretory production of heterologous proteins in Bacillus subtilis. J. Agric. Food Chem. 66, 13141-13151. doi: 10.1021/acs.jafc.8b04183

Gao, D., Luan, Y., Liang, Q., and Qi, Q. (2016). Exploring the N-terminal role of a heterologous protein in secreting out of Escherichia coli. Biotechnol. Bioeng. 113, 2561-2567. doi: 10.1002/bit.26028

Ghahremanifard, P., Rezaeinezhad, N., Rigi, G., Ramezani, F., and Ahmadian, G. (2018). Designing a novel signal sequence for efficient secretion of Candida antarctica lipase B in E. coli: The molecular dynamic simulation, codon optimization and statistical analysis approach. Int. J. Biol. Macromolecul. 119, 291-305. doi: 10.1016/j.ijbiomac.2018.07.150

Goosens, V. J., Monteferrante, C. G., and van Dijl, J. M. (2014). The Tat system of gram-positive bacteria. Biochim. Et Biophys. Acta Molecul. Cell Res. 1843, 1698-1706. doi: 10.1016/j.bbamcr.2013.10.008

Green, E. R., and Mecsas, J. (2016). Bacterial secretion systems: an overview. Microbiol. Spectr. 4. doi: 10.1128/microbiolspec.VMBF-0012-2015

Gu, Y., Zheng, J., Feng, J., Cao, M., Gao, W., Quan, Y., et al. (2017). Improvement of levan production in Bacillus amyloliquefaciens through metabolic optimization of regulatory elements. Appl. Microbiol. Biotechnol. 101, 4163-4174. doi: 10.1007/s00253-017-8171-2

Guan, C., Cui, W., Cheng, J., Liu, R., Liu, Z., Zhou, L., et al. (2016). Construction of a highly active secretory expression system via an engineered dual promoter and a highly efficient signal peptide in Bacillus subtilis. N. Biotechnol. 33, 372-379. doi: 10.1016/j.nbt.2016.01.005

Guan, C. R., Cui, W. J., He, X. T., Hu, X., Xu, J., Du, G. C., et al. (2015). Construction and development of a novel expression system of Streptomyces. Protein Expr. Purif. 113, 17-22. doi: 10.1016/j.pep.2015.04.009

Han, S., Machhi, S., Berge, M., Xi, G. L., Linke, T., and Schoner, R. (2017). Novel signal peptides improve the secretion of recombinant Staphylococcus aureus Alpha toxin(H35L) in Escherichia coli. AMB Exp. 7:93. doi: 10.1186/s13568-017-0394-1

Hemmerich, J., Rohe, P., Kleine, B., Jurischka, S., Wiechert, W., Freudl, R., et al. (2016). Use of a Sec signal peptide library from Bacillus subtilis for the optimization of cutinase secretion in Corynebacterium glutamicum. Microb. Cell Fact. 15:208. doi: 10.1186/s12934-016-0604-6

Herbort, M., Klein, M., Manting, E. H., Driessen, A. J. M., and Freudl, R. (1999). Temporal expression of the Bacillus subtilis secA gene, encoding a central component of the preprotein translocase. J. Bacteriol. 181, 493-500.

Hiller, K., Grote, A., Scheer, M., Munch, R., and Jahn, D. (2004). PrediSi: prediction of signal peptides and their cleavage positions. Nucleic Acids Res. 32, W375W379. doi: 10.1093/nar/gkh378

Inouye, S., Soberon, X., Franceschini, T., Nakamura, K., Itakura, K., and Inouye, M. (1982). Role of positive charge on the amino-terminal region of the signal peptide in protein secretion across the membrane. Proc. Natl. Acad. Sci. U.S.A. 79, 3438-3441. doi: 10.1073/pnas.79.11.3438

Ismail, N. F., Hamdan, S., Mahadi, N. M., Murad, A. M. A., Rabu, A., Abu Bakar, F. D., et al. (2011). A mutant l-asparaginase II signal peptide improves the secretion of recombinant cyclodextrin glucanotransferase and the viability of Escherichia coli. Biotechnol. Lett. 33, 999-1005. doi: 10.1007/s10529-011-0517-8

Jarjanazi, H., Savas, S., Pabalan, N., Dennis, J. W., and Ozcelik, H. (2008). Biological implications of SNPs in signal peptide domains of human proteins. ProteinsStruct. Funct. Bioinform. 70, 394-403. doi: 10.1002/prot.21548

Jonet, M. A., Mahadi, N. M., Murad, A. M. A., Rabu, A., Abu Bakar, F. D., Rahim, R. A., et al. (2012). Optimization of a heterologous signal peptide by site-directed mutagenesis for improved secretion of recombinant proteins in Escherichia coli. J. Mol. Microbiol. Biotechnol. 22, 48-58. doi: 10.1159/0003 36524

Kaell, L., Krogh, A., and Sonnhammer, E. L. L. (2007). Advantages of combined transmembrane topology and signal peptide prediction - the Phobius web server. Nucleic Acids Res. 35, W429-W432. doi: 10.1093/nar/gkm256

Kalbarczyk, K. Z., Mazeau, E. J., Rapp, K. M., Marchand, N., Koffas, M. A. G., and Collins, C. H. (2018). Engineering Bacillus megaterium strains to secrete cellulases for synergistic cellulose degradation in a microbial community. ACS Synth. Biol. 7, 2413-2422. doi: 10.1021/acssynbio.8b00186
Kleiner-Grote, G. R. M., Risse, J. M., and Friehs, K. (2018). Secretion of recombinant proteins from E. coli. Eng. Life Sci. 18, 532-550. doi: 10.1002/elsc.201700200

Kyte, J., and Doolittle, R. F. (1982). A simple method for displaying the hydropathic character of a protein. J. Mol. Biol. 157, 105-132. doi: 10.1016/0022-2836(82)90515-0

Low, K. O., Mahadi, N. M., and Illias, R. M. (2013). Optimisation of signal peptide for recombinant protein secretion in bacterial hosts. Appl. Microbiol. Biotechnol. 97, 3811-3826. doi: 10.1007/s00253-013-4831-z

Maffei, B., Francetic, O., and Subtil, A. (2017). Tracking proteins secreted by bacteria: what's in the toolbox. Front. Cell. Infect. Microbiol. 7:221. doi: 10.3389/fcimb.2017.00221

Mathiesen, G., Sveen, A., Brurberg, M. B., Fredriksen, L., Axelsson, L., and Eijsink, V. G. H. (2009). Genome-wide analysis of signal peptide functionality in Lactobacillus plantarum WCFS1. BMC Genomics 10:425. doi: 10.1186/1471-2164-10-425

Mergulhao, F. J. M., Summers, D. K., and Monteiro, G. A. (2005). Recombinant protein secretion in Escherichia coli. Biotechnol. Adv. 23, 177-202. doi: 10.1016/j.biotechadv.2004.11.003

Molhoj, M., and Dal Degan, F. (2004). Leader sequences are not signal peptides. Nat. Biotechnol. 22, 1502-1502. doi: 10.1038/nbt1204-1502

Mordkovich, N. N., Okorokova, N. A., and Veiko, V. P. (2015). Structural and functional organization of the signal peptide of pro-enterotoxin B from Staphylococcus aureus. Appl. Biochem. Microbiol. 51, 641-648. doi: $10.1134 /$ S0003683815060101

Musik, J. E., Zalucki, Y. M., Day, C. J., and Jennings, M. P. (2019). Efficient function of signal peptidase 1 of Escherichia coli is partly determined by residues in the mature N-terminus of exported proteins. Biochim. Biophys. Acta Biomembr. 1861, 1018-1022. doi: 10.1016/j.bbamem.2019.03.001

Nesmeyanova, M. A., Karamyshev, A. L., Karamysheva, Z. N., Kalinin, A. E., Ksenzenko, V. N., and Kajava, A. V. (1997). Positively charged lysine at the $\mathrm{N}$-terminus of the signal peptide of the Escherichia coli alkaline phosphatase provides the secretion efficiency and is involved in the interaction with anionic phospholipids. FEBS Lett. 403, 203-207. doi: 10.1016/S0014-5793(97)00052-5

Ng, D. T. W., and Sarkar, C. A. (2013). Engineering signal peptides for enhanced protein secretion from Lactococcus lactis. Appl. Environ. Microbiol. 79, 347-356. doi: 10.1128/AEM.02667-12

Owji, H., Nezafat, N., Negandaripour, M., Hajiebrahimi, A., and Ghasemi, Y. (2018). A comprehensive review of signal peptides: structure, roles, and applications. Eur. J. Cell Biol. 97, 422-441. doi: 10.1016/j.ejcb.2018.06.003

Palmer, T., and Berks, B. C. (2012). The twin-arginine translocation (Tat) protein export pathway. Nat. Rev. Microbiol. 10, 483-496. doi: 10.1038/nrmicro2814

Petersen, T. N., Brunak, S., von Heijne, G., and Nielsen, H. (2011). SignalP 4.0: discriminating signal peptides from transmembrane regions. Nat. Methods 8 , 785-786. doi: 10.1038/nmeth.1701

Quax, W. J. (1997). Merits of secretion of heterologous proteins from industrial microorganisms. Folia Microbiol. 42, 99-103. doi: 10.1007/BF02898715

Ravn, P., Arnau, J., Madsen, S. M., Vrang, A., and Israelsen, H. (2003). Optimization of signal peptide SP310 for heterologous protein production in Lactococcus lactis. Microbiology-Sgm 149, 2193-2201. doi: 10.1099/mic.0.26299-0

Rose, R. W., Bruser, T., Kissinger, J. C., and Pohlschroder, M. (2002). Adaptation of protein secretion to extremely high-salt conditions by extensive use of the twin-arginine translocation pathway. Mol. Microbiol. 45, 943-950. doi: 10.1046/j.1365-2958.2002.03090.x

Schiebel, E., Driessen, A. J., Hartl, F. U., and Wickner, W. (1991). Delta mu H+ and ATP function at different steps of the catalytic cycle of preprotein translocase. Cell 64, 927-939. doi: 10.1016/0092-8674(91)90317-R

Sewalt, V., Shanahan, D., Gregg, L., La Marta, J., and Carrillo, R. (2016). The generally recognized as safe (GRAS) process for industrial microbial enzymes. Indust. Biotechnol. 12, 295-302. doi: 10.1089/ind.2016.0011

Sone, Y. F., Nikoloff, J. M., and Zhang, D. W. (2015). Improving protein production on the level of regulation of both expression and secretion pathways in Bacillus subtilis. J. Microbiol. Biotechnol. 25, 963-977. doi: 10.4014/jmb.1501.01028

Takimura, Y., Kato, M., Ohta, T., Yamagata, H., and Udaka, S. (1997). Secretion of human interleukin-2 in biologically active form by Bacillus brevis 
directly into culture medium. Biosci. Biotechnol. Biochem. 61, 1858-1861. doi: 10.1271/bbb.61.1858

Terpe, K. (2006). Overview of bacterial expression systems for heterologous protein production: from molecular and biochemical fundamentals to commercial systems. Appl. Microbiol. Biotechnol. 72, 211-222. doi: $10.1007 / \mathrm{s} 00253-006-0465-8$

Tjalsma, H., Antelmann, H., Jongbloed, J. D. H., Braun, P. G., Darmon, E., Dorenbos, R., et al. (2004). Proteomics of protein secretion by Bacillus subtilis: separating the "Secrets" of the Secretome. Microbiol. Molecul. Biol. Rev. 68, 207-233. doi: 10.1128/MMBR.68.2.207-233.2004

Tjalsma, H., Bolhuis, A., Jongbloed, J. D. H., Bron, S., and van Dijl, J. M. (2000). Signal peptide-dependent protein transport in Bacillus subtilis: a genomebased survey of the secretome. Microbiol. Molecul. Biol. Rev. 64, 515-547. doi: 10.1128/MMBR.64.3.515-547.2000

Tsirigotaki, A., De Geyter, J., Sostaric, N., Economou, A., and Karamanou, S. (2017). Protein export through the bacterial Sec pathway. Nat. Rev. Microbiol. 15, 21-36. doi: 10.1038/nrmicro.2016.161

Tsuji, S., Tanaka, K., Takenaka, S., and Yoshida, K. (2015). Enhanced secretion of natto phytase by Bacillus subtilis. Biosci. Biotechnol. Biochem. 79, 1906-1914. doi: 10.1080/09168451.2015.1046366

Tsukazaki, T., Mori, H., Echizen, Y., Ishitani, R., Fukai, S., Tanaka, T., et al. (2011). Structure and function of a membrane component SecDF that enhances protein export. Nature 474, 235-238. doi: 10.1038/nature09980

Vezzoli, V., Duminuco, P., Vottero, A., Kleinau, G., Schulein, R., Minari, R., et al. (2015). A new variant in signal peptide of the human luteinizing hormone receptor (LHCGR) affects receptor biogenesis causing leydig cell hypoplasia. Hum. Mol. Genet. 24, 6003-6012. doi: 10.1093/hmg/ ddv313

von Heijne, G. (1985). Signal sequences. The limits of variation. J. Molecul. Biol. 184, 99-105. doi: 10.1016/0022-2836(85)90046-4

von Heijne, G. (1990). The signal peptide. J. Membr. Biol. 115, 195-201. doi: $10.1007 / \mathrm{BF} 01868635$ von Heijne, G. (1998). Protein transport - Life and death of a signal peptide. Nature 396, 111-113. doi: 10.1038/24036

Walsh, G. (2018). Biopharmaceutical benchmarks 2018. Nat. Biotechnol. 36, 1136-1145. doi: 10.1038/nbt.4305

Watanabe, K., Tsuchida, Y., Okibe, N., Teramoto, H., Suzuki, N., Inui, M., et al. (2009). Scanning the Corynebacterium glutamicum $\mathrm{R}$ genome for high-efficiency secretion signal sequences. Microbiol. Sgm 155, 741-750. doi: 10.1099/mic.0.024075-0

Wrighton, K. H. (2018). TRANSCRIPTION Shedding light on alternative promoter selection. Nat. Rev. Genet. 19:4. doi: 10.1038/nrg.2017.100

Wu, S. C., Ye, R. Q., Wu, X. C., Ng, S. C., and Wong, S. L. (1998). Enhanced secretory production of a single-chain antibody fragment from Bacillus subtilis by coproduction of molecular chaperones. J. Bacteriol. 180, 2830-2835.

Zhang, W., Yang, M., Yang, Y., Zhan, J., Zhou, Y., and Zhao, X. (2016). Optimal secretion of alkali-tolerant xylanase in Bacillus subtilis by signal peptide screening. Appl. Microbiol. Biotechnol. 100, 8745-8756. doi: 10.1007/s00253-016-7615-4

Zhou, Y. Z., Liu, P., Gan, Y. T., Sandoval, W., Katakam, A. K., Reichelt, M., et al. (2016). Enhancing full-length antibody production by signal peptide engineering. Microb. Cell Fact. 15:47. doi: 10.1186/s12934-016-0445-3

Conflict of Interest Statement: The authors declare that the research was conducted in the absence of any commercial or financial relationships that could be construed as a potential conflict of interest.

Copyright (c) 2019 Peng, Shi, Cao, Li, Liu and Lu. This is an open-access article distributed under the terms of the Creative Commons Attribution License (CC BY). The use, distribution or reproduction in other forums is permitted, provided the original author(s) and the copyright owner(s) are credited and that the original publication in this journal is cited, in accordance with accepted academic practice. No use, distribution or reproduction is permitted which does not comply with these terms. 